\title{
Seasonal Variation in Plant Species in the Vicinities of Chimdi Lake in Sunsari, Nepal
}

\author{
T.N. Mandal ${ }^{1}$, K.K.C. Poudel ${ }^{1}$ and T.P. Gautam ${ }^{2 *}$ \\ ${ }^{1}$ Department of Botany, Post Graduate Campus, Tribhuvan University, Biratnagar \\ ${ }^{2}$ Department of Botany, M.M.A.M. Campus, T.U., Biratnagar \\ *E-mail: tilak673@yahoo.com
}

Received: 19.07.2010, Accepted: 21.10.2010

\begin{abstract}
The plant species composition of the Chimdi lake area showed seasonal variation. Altogether 54 plant species under 21 families, 41 plant species under 19 families and 29 plants species under 14 families have been recorded in summer, rainy and winter seasons respectively. Dominant families were Poaceae 22.2\%, Cyperaceae $24.4 \%$ and again Poaceae $31 \%$ in the above respective seasons. The dicot and monocot members were maximum in the summer and minimum in the winter.
\end{abstract}

Key words: Seasonal variation, plant species composition, Chimdi lake, Nepal

\section{Introduction}

Wetlands are the sites characterized by the presence of water and occupy the place between the land and deep water habitats. These sites have unique soils which differ from adjacent uplands and supports vegetation adapted to waterlogged and submerged aquatic conditions. Aquatic environment may be classified into three types on the basis of variation in salt concentration of water. They include marine (concentration of salt- $35.0 \mathrm{~g} / \mathrm{l}$ ), estuarine (concentration of salt is $5.0 \mathrm{~g} / \mathrm{l}$ ) and freshwater environment (concentration of salt is $1-3.5 \mathrm{~g} / \mathrm{l}$ ). In Nepal, wetlands are only of freshwater type and are broadly classified into two categories, natural and man made. The natural wetlands include lakes, ponds, riverine flood plains, swamps and marshes, while man made wetlands include water storage area and deep-water agricultural land (IUCN, 1996). Wetlands of the Terai region substantially support the endangered species of wildlife. In Terai, out of 163 wetland sites highest number of wetland site is represented by lakes and ponds (78), followed by riverine flood plains (53) of the total wetland sites in Nepal. The least number is represented by swamps (5) and reservoir (6).

Wetlands are the most productive ecosystem and are thus important natural resources for economic and sustainable development. They play a very important role in maintaining biodiversity, bioproductivity and ecological productivity. Their significance in terms of ecological, biological, economical, sociological, cultural, religious, recreational and aesthetic values has always been appreciated. Wetlands support to provide tremendous socio- economic benefits to mankind through agricultural production, 
T.N. Mandal, K.K.C. Poudel and T.P. Gautam / Our Nature (2010) 8: 157-163

aquaculture, wood and timber production.

Numerous works have been done in the past on different aspects of limnology outside Nepal. But, there is very little work done on the wetland vegetation in Nepal, even though it is rich in having a wide range of aquatic vegetation, riverine forest, marshlands and grasslands. Some information on aquatic and wetland plants found in seasonally inundated flood plains of Nepal was mentioned in earlier works of Stainton (1972).

Jones et al. (1989) studied fifty lakes during their limnological work in Nepal. They studied ionic concentration, nitrogen and suspended solids. The lake productivity was limited by nitrogen, however, nutrients ratio varies seasonally, so the limiting nutrients could change to phosphorus. Mc Eachern (1993) studied physico-chemical characteristics of water in six sites in Chitawan district. He observed $\mathrm{pH}$ 7.2-7.5 and dissolved oxygen ranging from 0.5-4.3 $\mathrm{mg} / \mathrm{l}$ in Devital. In biodiversity assessment of terai wetlands done under BPP (1996) different macrophytes in various wetland sites have been reported. In Ghodaghodi tal, plant species such as Azolla, Lemna, Wolffia etc., were free floating species, Hydrilla, Chara, Potamogeton the submerged species, Ludwigia adscendens, Potamogeton natans, Nymphoides as the rooted floating species, Limnophylla as the emergent species. There is a rich growth of Salix tetrasperma scrubs in open water of the lake. Bhandari (1996), in his study "An inventory of Nepal's Terai Wetlands" presented 163 wetlands of Terai with their location and characteristic features. He also generated the primary data on physical, biological, limnological, hydrological and socio-economic information. About 172 species of the major wetland plants were listed by IUCN, Nepal (1996). Bhatta et al. (1999) studied physico-chemical characteristics and phytoplanktons of Taudaha lake, Kathmandu and reported that lake water exhibited richness in nitrogen and orthophosphate which favored the growth of phytoplankton.

At present, the Chimdi lake is at the process of restoration. Some of the area of lake (19 ha) has been impounded in 2001. Since then restoration process is going on in the impoundment area of the lake. An aquatic habitat has been redeveloped which comprises different forms of macrophytes and their location in the lake. The present study has been carried out to enumerate the plant species found in the vicinities of impounded area of Chimdi lake in different seasons.

The study site, Chimdi lake is located at Chimdi Village Development Committee (VDC), which lies in south eastern part of Sunsari district in eastern Nepal. Chimdi VDC is situated between $87^{\circ} 9^{\prime}-87^{\circ} 13^{\prime} \mathrm{E}$ and $26^{\circ} 28^{\prime}-26^{\circ} 31^{\prime} \mathrm{N}$. The climate of Chimdi lake area is tropical monsoon type. The year is divisible into three distinct seasons: dry and warm summer season (March to May), wet and warm rainy season (May to October) and dry and cool winter season (MidNovember to February). Based on climate data for 1994-2003, average annual mean monthly minimum temperature ranged from $8.34^{\circ} \mathrm{C}$ (January) to $25.9^{\circ} \mathrm{C}$ (August) and mean monthly maximum temperature ranged from $22.2^{\circ} \mathrm{C}$ (January) to $32.9^{\circ} \mathrm{C}$ (June). Climatological records show that average annual rainfall is $1829.8 \mathrm{~mm}$ of which $79 \%$ occurred from June to September (rainy season).

\section{Materials and methods}


T.N. Mandal, K.K.C. Poudel and T.P. Gautam / Our Nature (2010) 8: 157-163

The plants were collected in summer, rainy and winter season around the vicinities of lake. They were identified with the help of herbarium specimens and available literatures at Tribhuvan University Herbarium, Department of Botany, Post Graduate Campus, Biratnagar. The valid names of the species concerned are adopted after Press et al. (2000).

\section{Results}

Altogether 54 plant species belonging to 21 families were collected in summer season. (Tab. 1). On the basis of number of species, Poaceae was the largest family contributing $22.2 \%$ of total strength of families. Four larger families were in the following order: Poaceae > Cyperaceae > Asteraceae > Acanthaceae.

Similarly, 41 plant species belonging to 19 families were collected in rainy season (Tab. 2). Out of 41 species only a few like Ceratopteris thallictrodies (L.) Brong, Ludwigia adescendens (L.) Hara, Marsilea crenata Presl., Eleocharis acutangula (Roxb.) Schutt, Ipomoea aquatica Forssk., Sacciolepsis interrupta (R.Br.) and Sagittaria sagittifolia Auct. hon. L., Hook. f. were aquatic species. On the basis of number of species, Cyperaceae was the largest family contributing $24.4 \%$ of total strength of families. Four larger families were in the following order: Cyperaceae > Poaceae $>$ Fabaceae $>$ Acanthaceae.

Twenty eight plant species belonging to 14 families were collected in winter season (Tab. 3). On the basis of number of species, Poaceae was the largest family with 9 species contributing $31 \%$ of total strength of families. Four larger families were in the following order: Poaceae > Asteraceae > Euphorbiaceae $>$ Acanthaceae.
Distinct seasonal variation was observed in species richness and family diversity of the plant species found in the vicinities of Chimdi lake. Species richness and diversity of families were maximum in summer season (Tab. 4). These parameters showed decreasing trend towards rainy to winter and were minimum (species richness 28 and family diversity 14) in the winter season. In the winter season most of the Cyperaceae members disappeared which were abundant in the rainy season. So, in the winter season dominance is shifted to Poaceae, while members of Asteraceae become second dominant.

Similarly, the seasonality was also observed in the availability of dicot, monocot and other members in the lake area (Tab. 5). The dicot and monocot members were maximum in the summer and minimum in the winter. Moreover, the dicot members were higher in all the seasons than monocot.

\section{Discussion}

On the basis of number of species, family distribution revealed that Poaceae was found as the dominant family in the summer season and Cyperaceae was represented as second dominant family in that season. Cyperaceae was dominant family in the rainy season while Poaceae was second dominant. Similarly, Poaceae was largest dominant family in winter season and Asteraceae was second. In the winter season most of the Cyperaceae members disappeared which were once abundant in the rainy season. So, in the winter season dominance is shifted to Poaceae and Asteraceae become the second dominant family.

Distinct seasonal variation was 
T.N. Mandal, K.K.C. Poudel and T.P. Gautam / Our Nature (2010) 8: 157-163

Table 1. Enumeration of plant species in summer season in the vicinities of Chimdi lake, Sunsari, Nepal.

\begin{tabular}{|c|c|c|c|}
\hline $\mathbf{S N}$ & Plant species & Local name & Family \\
\hline 1 & Alternanthera sessilis (L.) R.Br. ex DC. & Saraunchi & Amaranthaceae \\
\hline 2 & Amaranthus sp. & Latte sag & Amaranthaceae \\
\hline 3 & Axonopus compressus (SW) P. Beauv & Hade dubo & Poaceae \\
\hline 4 & Blumea sp. & Gandhe jhar & Asteraceae \\
\hline 5 & Cyperus compactus Retz. & - & Cyperaceae \\
\hline 6 & Caesulia axillaris Roxb. & - & Asteraceae \\
\hline 7 & Centella asiatica (L.) Urb. & Ghodtapre & Apiaceae \\
\hline 8 & Chara sp. & - & Characeae \\
\hline 9 & Chrysopogon aciculatus L. & - & Poaceae \\
\hline 10 & Cyperus compresus L (Chota-della) & - & Cyperaceae \\
\hline 11 & Commelina benghalensis L. & Kane jhar & Commelinaceae \\
\hline 12 & Cynodon dactylon (L.) Pers. & Dubo & Poaceae \\
\hline 13 & Cyperus diformis $\mathrm{L}$. & Mothe & Cyperaceae \\
\hline 14 & Cyperus iria $\mathrm{L}$. & Mothe & Cyperaceae \\
\hline 15 & Cyperus pilosus Vahl & Thulomothe & Cyperaceae \\
\hline 16 & Cyperus rotundus $\mathrm{L}$. & Mothe & Cyperaceae \\
\hline 17 & Cyperus exalatus Retz. & - & Cyperaceae \\
\hline 18 & Desmodium triflorum (L.) DC. & Tinpate & Fabaceae \\
\hline 19 & Digittaria setigera Roth ex R. \& S. & Banso & Poaceae \\
\hline 20 & Dryopteris cochleata (D. Don) P. Beauv & Ghiu niguro & Polypodiaceae \\
\hline 21 & Echinochloa colonum $\mathrm{L}$. & Jhiro & Poaceae \\
\hline 22 & Echinochloa crus-galli (L.) P. Beauv & Chirchiro & Poaceae \\
\hline 23 & Eclipta prostrata (L.) L. Mant. & Bhringaraj & Asteraceae \\
\hline 24 & Eichhornia crassipes (Mart) Solms & Jalkumbhi & Pontederiaceae \\
\hline 25 & Eleocharis acutangula (Roxb.) Schutt. & - & Cyperaceae \\
\hline 26 & Eleusine indica (L.) & Kode jhar & Poaceae \\
\hline 27 & Eragrostis uniloides (Retz.) Nees ex Steud. & - & Poaceae \\
\hline 28 & Evolvulus alsinoides L. & - & Convolvulaceae \\
\hline 29 & Gnaphalium pensylvanicum Wild. & Bhui buki & Asteraceae \\
\hline 30 & Hedyotis sp. & - & Rubiaceae \\
\hline 31 & Hemarthria compressa (L.f.) R.Br. & Ghode dubo & Poaceae \\
\hline 32 & Hemigraphis hirta (Bihl.) T. Anders. & - & Acanthaceae \\
\hline 33 & Hygrophilla auriculata (Schum.) Heine & - & Acanthaceae \\
\hline 34 & Hygrophilla polysperma (Roxb.) T. Anders. & - & Acanthaceae \\
\hline 35 & Imperata cylindrica (L.) Raeurch & Siru & Poaceae \\
\hline 36 & Ipomoea aquatica Forssk. & Kaami sag & Convolvulaceae \\
\hline 37 & Kyllinga brevifolia Rottb. & - & Cyperaceae \\
\hline 38 & Lidernia parviflora (Roxb.) Haines & - & Scrophulariaceae \\
\hline 39 & Ludwigia adescendens (L.) Hara & - & Onagraceae \\
\hline 40 & Ludwigia octovalis (Jacq.) Raven & - & Onagraceae \\
\hline 41 & Marsilea crenata Presl. & Charpate & Marsiliaceae \\
\hline 42 & Mecardonia procumbens (Mill.) Small & - & Scrophulariaceae \\
\hline 43 & Mimosa pudica $\mathrm{L}$. & Lajawati & Fabaceae \\
\hline 44 & Paspalum distichum $\mathrm{L}$. & - & Poaceae \\
\hline 45 & Phyllanthus sp. & - & Euphorbiaceae \\
\hline 46 & Polygonum barbatum $\mathrm{L}$. & Pirre jhar & Polygonaceae \\
\hline 47 & Polygonum plebium R.Br. & Pirre jhar & Polygonaceae \\
\hline 48 & Ranunculus scleratus $\mathrm{L}$. & - & Ranunculaceae \\
\hline 49 & Rungea pectinata (L.) Nees & - & Acanthaceae \\
\hline 50 & Sacciolepsis interrupta (R.Br.) A.Camus & Pani ghas & Poaceae \\
\hline
\end{tabular}


T.N. Mandal, K.K.C. Poudel and T.P. Gautam / Our Nature (2010) 8: 157-163

51 Sagittaria sagittifolia Auct. hon.L.,hook.f. Laph

52 Schoenoplectus mucronatus (L.) Palla

53 Sida rhombifolia L.

54 Sphaeranthus indicus $\mathrm{L}$.

$\begin{array}{ll}- & \text { Alismataceae } \\ - & \text { Cyperaceae } \\ \text { Khareto } & \text { Malvaceae } \\ - & \text { Khareto }\end{array}$

Table 2. Enumeration of plant species in rainy season in the vicinities of Chimdi lake, Sunsari, Nepal.

\begin{tabular}{|c|c|c|c|}
\hline $\mathbf{S N}$ & Plant species & Local name & Family \\
\hline 1 & Alternanthera sessilis (L.) R.Br. ex DC. & Saraunchi & Amaranthaceae \\
\hline 2 & Anagalis sp. & - & Primulaceae \\
\hline 3 & Blumea sp. & Gandhe jhar & Asteraceae \\
\hline 4 & Centella asiatica (L.) Urb. & Ghodtapre & Apiaceae \\
\hline 5 & Ceraptopteris thalictrodies (L.) Brong. & - & Parkeriaceae \\
\hline 6 & Chrysopogon aciculatus $\mathrm{L}$. & - & Poaceae \\
\hline 7 & Commelina benghalensis $\mathrm{L}$. & Kane jhar & Commelinaceae \\
\hline 8 & Cynodon dactylon(L.) Pers. & Dubo & Poaceae \\
\hline 9 & Cyperus compactus Retz. & - & Cyperaceae \\
\hline 10 & Cyperus compresus L (Chota-della) & - & Cyperaceae \\
\hline 11 & Cyperus diformis $\mathrm{L}$. & Mothe & Cyperaceae \\
\hline 12 & Cyperus exalatus Retz. & - & Cyperaceae \\
\hline 13 & Cyperus iria $\mathrm{L}$. & Mothe & Cyperaceae \\
\hline 14 & Cyperus pilosus Vahl. & Thulomothe & Cyperaceae \\
\hline 15 & Cyperus rotundus $\mathrm{L}$. & Mothe & Cyperaceae \\
\hline 16 & Desmodium triflorum (L.) DC. & Tinpate & Fabaceae \\
\hline 17 & Eclipta prostrata (L.) L. Mant. & Bhringaraj & Asteraceae \\
\hline 18 & Eleocharis acutangula (Roxb.) Schutt. & - & Cyperaceae \\
\hline 19 & Eleusine indica (L.) & Kode jhar & Poaceae \\
\hline 20 & Eriocaulon $\mathrm{sp}$. & - & Eriocaulaceae \\
\hline 21 & Evolvulus alsinoides $\mathrm{L}$. & - & Convolvulaceae \\
\hline 22 & Fimbristylis dichotoma (L.) Vahl. & Badami jhar & Cyperaceae \\
\hline 23 & Hedyotis sp. & - & Rubiaceae \\
\hline 24 & Hemarthria compressa (L.f.) R.Br. & Ghode dubo & Poaceae \\
\hline 25 & Hemigraphis hirta (Bihl.) T. Anders. & - & Acanthaceae \\
\hline 26 & Hygrophilla auriculata (Schum.) Heine & - & Acanthaceae \\
\hline 27 & Hygrophilla polysperma (Roxb.) T. Anders. & - & Acanthaceae \\
\hline 28 & Imperata cylindrica $($ L.) Raeurch & Siru & Poaceae \\
\hline 29 & Ipomoea aquatica Forssk. & Kamisag & Convolvulaceae \\
\hline 30 & Kyllinga brevifolia Rottb. & - & Cyperaceae \\
\hline 31 & Ludwigia adescendens (L.) Hara & - & Onagraceae \\
\hline 32 & Ludwigia octovalis (Jacq.) Raven & - & Onagraceae \\
\hline 33 & Marsilea crenata Presl. & Charpate & Marsiliaceae \\
\hline 34 & Mecardonia procumbens (Mill.) Small & - & Scrophulariaceae \\
\hline 35 & Mimosa pudica $\mathrm{L}$. & Lajawati & Fabaceae \\
\hline 36 & Paspalum distichum $\mathrm{L}$. & - & Poacaea \\
\hline 37 & Phyllanthus sp. & - & Euphorbiaceae \\
\hline 38 & Polygonum barbatum $\mathrm{L}$. & Pirre jhar & Polygonaceae \\
\hline 39 & Sacciolepsis interrupta (R.Br.) A. Camus & Pani ghans & Poaceae \\
\hline 40 & Sagittaria sagittifolia Auct. hon.L., hook.f.Laph & - & Alismataceae \\
\hline 41 & Sesbania aculenta (Wild.) Pers. & Dhaincha & Fabaceae \\
\hline
\end{tabular}


T.N. Mandal, K.K.C. Poudel and T.P. Gautam / Our Nature (2010) 8: 157-163

Table 3. Enumeration of plant species in winter season in the vicinities of Chimdi lake, Sunsari, Nepal.

\begin{tabular}{llll}
\hline SN & Plant species & Local name & Family \\
\hline 1 & Alternanthera sessilis (L.) R.Br. ex DC. & Saraunchi & Amaranthaceae \\
2 & Axonopus compressus (Sw) P. Beauv & Hade dubo & Poaceae \\
3 & Blumea sp. & Gandhe jhar & Asteraceae \\
4 & Caesulia axillaris Roxb. & - & Asteraceae \\
5 & Centella asiatica (L.) Urb. & Ghodtapre & Apiaceae \\
6 & Chrysopogon aciculatus L. & - & Poaceae \\
7 & Commelina benghalensis L. & Kane jhar & Commelinaceae \\
8 & Croton bonplandianum Baill & Khursanejhar & Commelinaceae \\
9 & Cynodon dactylon (L.) Pers. & Dubo & Poaceae \\
10 & Desmodium triflorum (L.) DC. & Tinpate & Fabaceae \\
11 & Digittaria setigera Roth ex R.\& S. & Banso & Poaceae \\
12 & Eclipta prostrata (L.) L. Mant. & Bhringaraj & Asteraceae \\
13 & Eragrostis uniloides & - & Poaceae \\
14 & Evolvulus alsinoides L. & - & Convolvulaceae \\
15 & Fimbristylis dichotoma (L.) Vahl. & Badami jhar & Cyperaceae \\
16 & Gnaphalium pensylvanicum Wild. & Bhuibuki & Asteraceae \\
17 & Hemarthria compressa (L.f.) R.Br. & Ghode dubo & Poaceae \\
18 & Imperata cylindrica (L.) Raeurch & Siru & Poaceae \\
19 & Leucas indica (L.) R. Br. ex Vatke & Dulphi & Lamiaceae \\
20 & Mecardonia procumbens (Mill.) Small & - & Scrophulariaceae \\
21 & Paspalum distichum L. & - & Poaceae \\
22 & Phyllanthus sp. & - & Euphorbiaceae \\
23 & Polygonum barbatum L. & Pirre jhar & Polygonaceae \\
24 & Rungea pectinata (L.) Nees & - & Acanthaceae \\
25 & Saccharum spontaneum L. & Kans & Poaceae \\
26 & Sida rhombifolia L. & Khareto & Malvaceae \\
27 & Sonchus asper (L.) Hill & - & Asteraceae \\
28 & Sphaeranthus indicus L. & - & Asteraceae \\
\hline
\end{tabular}

Table 4. Seasonal variation in species richness and family diversity of the plant species found in the vicinities of Chimdi lake, eastern Nepal.

\begin{tabular}{lcc}
\hline Season & Species richness & Family diversity \\
\hline Summer & 54 & 21 \\
Rainy & 41 & 19 \\
Winter & 28 & 14 \\
\hline
\end{tabular}

Table 5. Seasonal variation in the dicot, monocot and other members in the vicinities of Chimdi lake, eastern Nepal.

\begin{tabular}{lccccc}
\hline Season & Dicot & Monocot & Dicot:Monocot & Others & Total \\
\hline Summer & 29 & 22 & 1.3 & 3 & 54 \\
Rainy & 22 & 17 & 1.3 & 2 & 41 \\
Winter & 19 & 9 & 2.1 & - & 28 \\
\hline
\end{tabular}


observed in species richness and family diversity of the plant species. After winter, many plant species grow in the summer. So, species richness and family diversity are higher in summer and lower in winter. The number of dicot species was higher than monocots in all seasons. Especially in the winter most of the monocots are disappeared. So, the ratio of dicots and monocots is distinctly higher in the winter.

The Chimdi lake shows seasonal variation in the wetland communities. During summer season drying of standing water in the eastern part of lake exposes the substrate and allows the germination of emergent species. Many species of Cyperus and other dicot plants eg. Eclipta, Polygonum, Ludwigia and Sesbania appeared in the dry marsh area. After rainfall, standing water returns and then submerged species quickly reappear as their seeds readily germinate in standing water.

Based upon different factors like presence and absence and quantity of water, water depth and seasonal changes in water area, wetlands may be classified into permanent and seasonal wetlands. Permanent wetlands develop where shallow moving or stagnant water remains perennial. Seasonal wetlands are restricted to areas which are only periodically inundated. Chimdi lake can be placed under seasonal wetland where water area and water depth changed seasonally. During rainy season most of the grassland area is filled with water. The water depth in the impoundment area also increases. But due to shallow nature, most of the plant of the lake dries during summer season which stimulate the generation of emergent species leading to terrestrial communities.

\section{References}

Bhandari, B. 1996. An inventory of Nepal's Terai Wetland. IUCN, Kathmandu, Nepal.

Bhatt, L., P. Lacoul, H.D. Lekhak and P.K. Jha 1999. Physico-chemical characteristics and phytoplanktons of Taudaha lake, Kathmandu. Poll. Res. 18(4): 353-358.

BPP (Biodiversity Profile Project) 1996. Biodiversity assessment of Terai Wetlands, HMGNepal/Government of Netherlands. pp. 18-20.

IUCN 1996. An inventory of Nepal's Wetlands. IUCN, Kathmandu, Nepal.

Jones, J.R., M.F. Knowlton and D.B. Swar 1989. Limnological reconnaissance of water bodies in central and southern Nepal. Hydrobiol. 184: 171-189.

Mc Eachern, P. 1993. Limnology National Wetland Survey. In Proceedings of the National workshop on Wetland Management in Nepal (Eds. T.B. Shrestha and B. Bhandari). IUCN, Kathmandu, Nepal.

Press, J.R., K.K. Shrestha and D.A. Sutton 2000. Annonated cheklist of the flowering plants of Nepal. The Natural History Museum, London. $430 \mathrm{p}$.

Stainton, J.D.A. 1972. Forest of Nepal. John Murray and Co., London. 